University of Nebraska - Lincoln

DigitalCommons@University of Nebraska - Lincoln

USDA National Wildlife Research Center - Staff Publications
U.S. Department of Agriculture: Animal and Plant Health Inspection Service

2013

\title{
Use of stormwater impoundments near airports by birds recognizedas hazardous to aviation safety
}

\author{
Brian J. Fox \\ Auburn University \\ Wesley B. Holland \\ Auburn University \\ Frank L. Boyd \\ US Department of Agriculture \\ Bradley F. Blackwell \\ US Department of Agriculture, bradley.f.blackwell@aphis.usda.gov \\ James B. Armstrong \\ Auburn University
}

Follow this and additional works at: https://digitalcommons.unl.edu/icwdm_usdanwrc

Part of the Life Sciences Commons

\begin{abstract}
Fox, Brian J.; Holland, Wesley B.; Boyd, Frank L.; Blackwell, Bradley F.; and Armstrong, James B., "Use of stormwater impoundments near airports by birds recognizedas hazardous to aviation safety" (2013). USDA National Wildlife Research Center - Staff Publications. 1227.

https://digitalcommons.unl.edu/icwdm_usdanwrc/1227
\end{abstract}

This Article is brought to you for free and open access by the U.S. Department of Agriculture: Animal and Plant Health Inspection Service at DigitalCommons@University of Nebraska - Lincoln. It has been accepted for inclusion in USDA National Wildlife Research Center - Staff Publications by an authorized administrator of DigitalCommons@University of Nebraska - Lincoln. 


\title{
Use of stormwater impoundments near airports by birds recognized as hazardous to aviation safety
}

\author{
Brian J. Fox ${ }^{\mathrm{a}}$, Wesley B. Holland ${ }^{\mathrm{a}}$, Frank L. Boyd ${ }^{\mathrm{b}}$, Bradley F. Blackwell ${ }^{\mathrm{c}, *}$, \\ James B. Armstrong ${ }^{\mathrm{B}}$ \\ a School of Forestry and Wildlife Sciences, Auburn University, 3301 Forestry and Wildlife Sciences Building, Auburn, AL 36849, USA \\ ${ }^{\mathrm{b}}$ US Department of Agriculture, Animal and Plant Health Inspection Service, Wildlife Services Alabama, 3301 Forestry and Wildlife Sciences Building, \\ Auburn, AL 36830, USA \\ c US Department of Agriculture, Animal and Plant Health Inspection Service, Wildlife Services, National Wildlife Research Center, Ohio Field Station, 6100 \\ Columbus Avenue, Sandusky, OH 44870, USA
}

\section{H I G H L I G H T S}

- Stormwater sites near airports attract birds hazardous to aviation safety.

- We modeled use of stormwater sites by birds involved in bird-aircraft collisions.

- Site features affecting cover and foraging contributed positively to use by birds.

- Design and management reducing water and cover availability can enhance safety.

\section{A R T I C L E I N F O}

\section{Article history:}

Received 3 January 2013

Received in revised form 11 June 2013

Accepted 13 June 2013

Available online 31 July 2013

\section{Keywords:}

Airport

Aviation hazard

Bird strike

Stormwater impoundment

US Federal Aviation Administration

\begin{abstract}
A B S T R A C T
Design of privately-owned stormwater impoundments within or near airport siting criteria has received little attention with regard to potential hazards posed to aviation safety. In particular, minimizing use of these impoundments by bird species recognized as hazardous to aviation poses an important challenge. Emergent vegetation, shoreline irregularity, and proximity of other water resources are linked to avian richness and diversity within wetlands, as well as bird use of stormwater impoundments on airports. We predicted also that impoundments with bank slope $>20 \%$ and those functioning as detention facilities, where water is periodically drawn down, would negatively influence use by birds; and that shorelinevegetation diversity and local land-use diversity would be positively correlated with use. Over 104 weeks (March 2008 to March 2010), we surveyed bird use of 40 stormwater impoundments in the AuburnOpelika Metropolitan area, Lee County, AL, USA, typical of privately-owned facilities located within or near airport siting criteria. We quantified local-scale and site-specific parameters possibly affecting bird use and evaluated fit for 17 a priori models relative to detection of 10 individual avian foraging guilds recognized as hazardous to aviation safety. Relative likelihoods of best-approximating models (Akaike weights) ranged from approximately 0.42 to 0.92 . Based on best-approximating models for at least five of the 10 guilds, we suggest that broad reduction in use of stormwater impoundments, located within or near airport siting criteria, by bird species hazardous to aviation can be achieved via designs which minimize perimeter, surface area, and the ratio of open water to emergent vegetation.
\end{abstract}

Published by Elsevier B.V.

\section{Introduction}

Collisions between wildlife and aircraft are a growing threat to civil aviation safety (Dolbeer, 2011). Of these wildlife strikes, bird-aircraft collisions (hereafter "bird strikes") are by far the greatest concern because of strike frequency and associated damage

\footnotetext{
* Corresponding author. Tel.: +1 4196250242.

E-mail addresses: brad.blackwell88@gmail.com, bradley.f.blackwell@aphis.usda.gov (B.F. Blackwell).
}

(DeVault, Belant, Blackwell, \& Seamans, 2011; Dolbeer, 2011). In the USA alone bird strikes to civil aviation result in industry losses exceeding US\$ 600 million annually (Dolbeer, Wright, Weller, \& Beiger, 2012), and over US\$ 1.2 billion annually worldwide (Allan, 2002). Dolbeer (2006) reported that $74 \%$ of bird strikes occur at $<152 \mathrm{~m}(500 \mathrm{ft})$ above ground level (AGL), airspace within an airport's air operations area (AOA; US Federal Aviation Administration, FAA, 2007), or in close proximity. The AOA encompasses all surface areas designed for aircraft movement including runways, taxiways and aprons. An underlying assumption regarding strikes within the AOA is that birds are attracted by habitat characteristics 
or resources in the immediate vicinity of the collision (Blackwell, DeVault, Fernández-Juricic, \& Dolbeer, 2009; Cleary \& Dolbeer, 2005). Therefore, bird strike-prevention efforts focus primarily on airport properties (Dolbeer, 2011), but management of wildlife attractants on adjoining properties is also important (Blackwell et al., 2009; DeVault et al., 2012; Martin et al., 2011).

In the USA, the FAA is responsible for advising airport managers and other stakeholders on managing attractants to potentially hazardous wildlife, and exerts regulatory control over airport certification and operation via Title 14 Code of Federal Regulations (CFR), Federal Aviation Regulations, Part 139-Certification of Airports. Specifically, the FAA (2007) instructs airport managers to address, and if possible eliminate, wildlife attractants within $1.5 \mathrm{~km}$ of the AOA for airports serving piston-powered aircraft and $3.0 \mathrm{~km}$ for airports serving turbine-powered aircraft. Notably, aircraft descending on a $3^{\circ}$ glideslope would be $\leq 152 \mathrm{~m}$ AGL at $3 \mathrm{~km}$ from the runway (Flight Safety Foundation, 2000), thus within the FAA siting criterion. However, the FAA and airports have limited regulatory roles over land uses off of airport property (including private property within siting criteria; Blackwell et al., 2009; DeVault et al., 2012).

Water resources within and near the AOA pose particular concerns because a variety of avian genera recognized as hazardous to aviation utilize open water (DeVault et al., 2011). Specifically, 13 of $52(25 \%)$ avian species involved in at least 50 total strikes reported to the FAA (1990-2008; summarized in the FAA Wildlife Strike Database; http://wildlife-mitigation.tc.faa.gov/wildlife/) have foraging and breeding ecologies primarily associated with water (Blackwell et al., 2013). Further, an analysis of water coverage at 49 CFR-Part 139 certificated airports revealed that surface water composed on average $6.0 \%$ ( $S D=10.4 \%$; range: $0.04-48.3 \%)$ of the area $(\bar{X}$ area $=275 \mathrm{ha}, \mathrm{SD}=511 \mathrm{ha})$ within the 3-km FAA siting criteria (Appendix A). Stormwater impoundments are constructed in and around airports to ensure environmental compliance with regard to water quality (http://www.faa. gov/airports/environmental/environmental_desk_ref/media/desk_ ref_chap6.pdf; see also Baier et al., 2003), as well as aircraft safety relative to redirecting runoff away from the AOA. However, these impoundments also serve to create wildlife habitat by providing standing water after storm or runoff events (Blackwell, Schafer, Helon, \& Linnell, 2008) or deicing operations (Airport Cooperative Research Program, 2009). Impoundments that do not drain completely can develop sediment deposits and vegetation complexes over time that support an array of invertebrate and vertebrate diversity (Brand \& Snodgrass, 2009; Le Viol, Mocq, Julliard, \& Kebiriou, 2009), thus offering potential foraging, loafing, roosting, and nesting space to a variety of bird species (e.g., Blackwell et al., 2008; Le Viol et al., 2009; Sparling, Eisemann, \& Kuenzel, 2007).

Unfortunately, the majority of research on bird use of stormwater impoundments has focused primarily on efforts to enhance these facilities as attractants (e.g., Adams, Dove, \& Franklin, 1985; Duffield, 1986; Sparling, Eisemann, \& Kuenzel, 2004; Sparling et al., 2007; see also Murray \& Hamilton, 2010; White \& Main, 2005). Far less effort has focused on understanding bird use of stormwater impoundments so as to reduce use by birds recognized by the FAA as posing hazards to aviation safety (e.g., Blackwell et al., 2008, 2009). For example, Blackwell et al. (2008) suggested that designs for on-airport stormwater impoundments in the Pacific Northwest, USA, should minimize perimeter and be located so as to reduce the number and proximity of other water resources within $1 \mathrm{~km}$. However, inherent to airport stormwater impoundments is some degree of post-construction management, regulated by the FAA, that can serve to reduce use by birds and other wildlife.

Our purpose was to better understand avian use of stormwater impoundments that are not regulated by the FAA, but typical of facilities that are found within or near airport siting criteria.
Table 1

Parameters pertaining to bird use of natural and man-made water resources and selected to compose 17 a priori models (see Table 2 developed to describe use of 40 stormwater impoundments in the Auburn-Opelika Metropolitan area, Lee County, AL, USA, by avian guilds recognized as hazardous to aviation safety (DeVault et al., 2011).

\begin{tabular}{ll}
\hline Co-variate & Source \\
\hline $\begin{array}{l}\text { Impoundment design (retention } \\
\text { vs. detention) } \\
\text { Surface area }\end{array}$ & Steen et al. (2006) \\
& Adams et al. (1985), Blackwell et al. \\
& (2008), Brown and Dinsmore (1986), \\
& Carbaugh et al. (2010) \\
Shoreline irregularity & Blackwell et al. (2008, and citations \\
& therein); Cicero (1989) \\
Ratio of proportion of open water & Blackwell et al. (2008); Duffield \\
to emergent vegetation & (1986); Hobaugh and Teer (1981); \\
& Weller and Spatcher (1965) \\
Isolation relative to area of other & Brown and Dinsmore (1986); \\
open-water resources within a & Blackwell et al. (2008); Duffield \\
defined radius & (1986); Dunton and Combs (2010) \\
Bank slope & DeGraaf et al. (1985); Duffield (1986); \\
& FAA AC 150/5200-33B \\
Vegetation diversity & Bancroft et al. (2002); Cicero (1989); \\
& Steen et al. (2006) \\
Land-use diversity & Blair (1996); Dykstra et al. (2001); \\
& Stout et al. (2006); Traut and Hostetler \\
& (2003) \\
Seasonal influences & Caula, Marty, and Martin (2008) \\
\hline
\end{tabular}

Emergent vegetation, shoreline irregularity, and proximity of other water resources are linked to avian richness and diversity within wetlands, as well as bird use of stormwater impoundments characteristic of FAA-regulated facilities on airports (Table 1). In addition to these factors, we predicted that impoundments with bank slopes $>20 \%$ and those functioning as detention facilities, where water is periodically drawn down, would negatively influence use by birds; and that shoreline-vegetation diversity and local land-use diversity would be positively correlated with use. Our specific objectives were to (1) quantify local-level features, as well as site-specific characteristics associated with privately-owned stormwater impoundments, within or near airport siting criteria, that might serve as bird attractants; and (2) make recommendations as to design of stormwater impoundments near airports to reduce attraction to birds recognized as hazardous to aviation.

\section{Materials and methods}

\subsection{Study area}

We conducted our study in the Auburn-Opelika Metropolitan area in Lee County, AL, USA, from March 2008 to March 2010 (Fig. 1). This region includes remnant tracts of longleaf pine (Pinus palustris), but much of this area has been converted to agriculture, timber production, or urban development (Commission for Environmental Cooperation, 1997).

\subsection{Impoundment selection}

We selected 40 stormwater impoundments (Fig. 1) to serve as surrogates for unregulated (by the FAA) impoundments that could be located within or near the 3-km siting criterion (FAA, 2007). These surrogate impoundments were generally located within approximately $5 \mathrm{~km}$ (10 sites within $10 \mathrm{~km}$ ) of a regional airport (Fig. 1), had characteristics typical to all stormwater impoundments, but were not all characteristic of FAA (2007) design and management recommendations (i.e., they included unmanaged or more natural shorelines). All sites contained inlet and outflow pipes, rip-rap areas and spillways, features common to stormwater impoundments in AL (Baier et al., 2003). In addition, all sites 


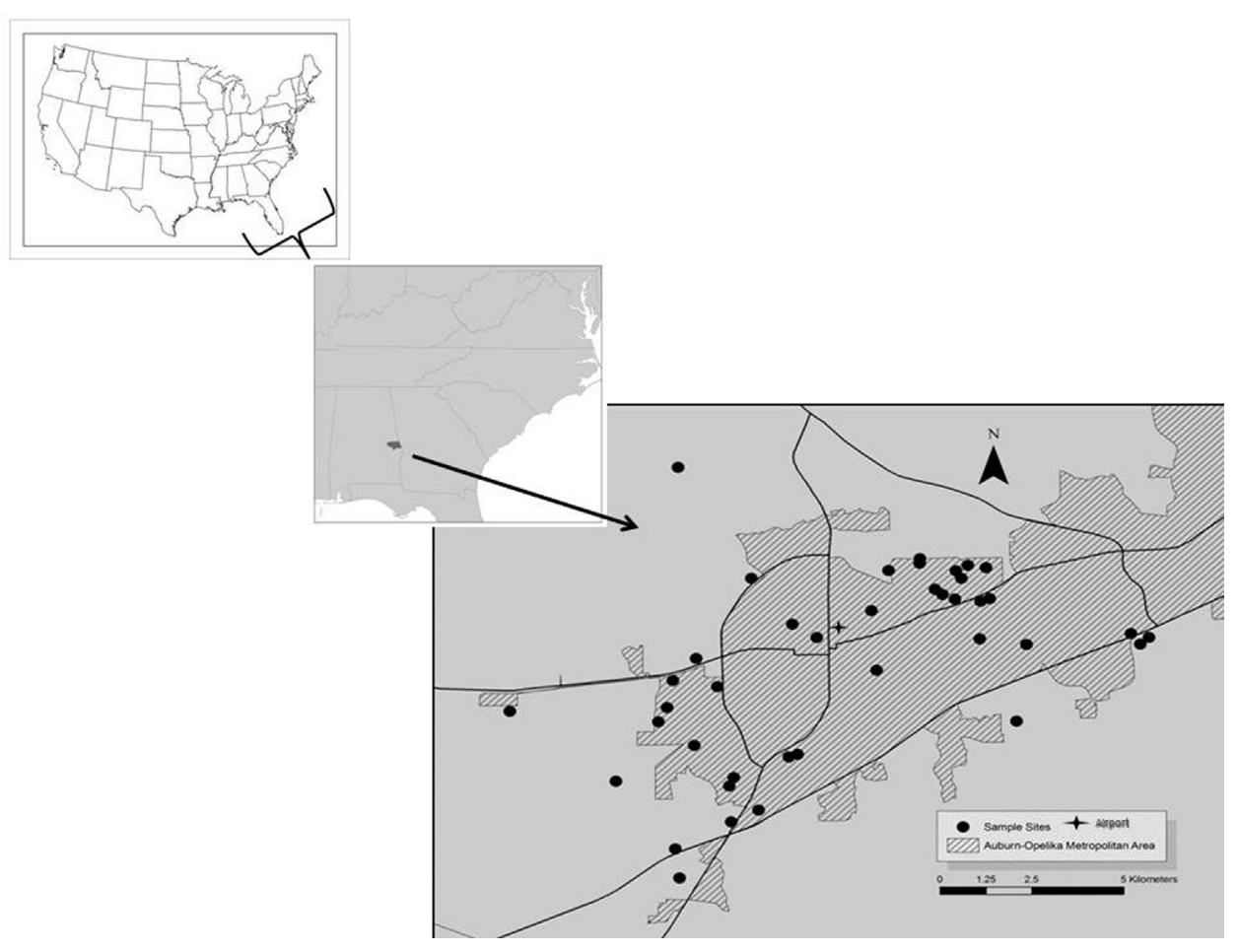

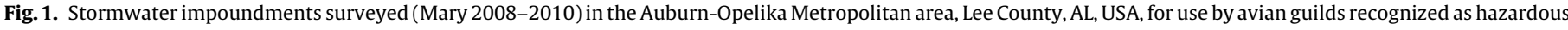
to aviation safety (DeVault et al., 2011).

retained water in the weeks prior to the beginning of field observations. Because of private ownership, final site selection depended upon access to properties from land owners.

\subsection{Sampling protocol}

We randomly assigned our sample of 40 impoundments to four groups of 10 impoundments each (sets A through D). Within each set no two impoundments were located within $1 \mathrm{~km}$ of each other. We surveyed each set for one calendar week (five days) on a rotating basis (beginning with set A), so that each set was surveyed once every four weeks. Within each survey week, each impoundment was surveyed in random order twice daily (ranging from $30 \mathrm{~min}$ to $2 \mathrm{~h}$ after sunrise and from $2 \mathrm{~h}$ to within $30 \mathrm{~min}$ of sunset). We focused our surveys on bird species composing 10 foraging guilds (e.g., DeGraaf, Tilghman, \& Anderson, 1985; Sibley, 2001) recognized as hazardous to aviation (DeVault et al., 2011): geese, dabbling ducks, diving ducks, and domestic/exotic waterfowl (all four guilds representing Anatidae); "blackbirds", considering Icteridae and Sternidae together; doves (Columbidae); diurnal birds of prey (hereafter, raptors; Accipitridae, Cathartidae, and Falconidae); shorebirds, including gulls (Charadriiformes); wading birds (Ciconiidae and Ardeidae); and Suliformes, including cormorants (Phalacrocoracidae) and anhingas (Anhingadae). Our sampling regimen provided 10 attempts to detect each guild per site within the sampling week.

Upon arrival to an impoundment, we conducted an initial "snapshot" count of all birds present in the impoundment basin or foraging immediately overhead. We followed this initial count with a 3-min walking survey of the impoundment's perimeter to flush birds (within $5 \mathrm{~m}$ of the shoreline) that might otherwise have gone undetected. Each count also included all individuals that arrived at the impoundment during the survey. Our approach was somewhat similar to the double-sampling method (Bart \& Earnst, 2002), in that we adjusted our initial count by including birds flushed during the walking component. We recorded individuals from all avian species observed at our experimental sites, and then organized observations by guild. Herein, we report only those species included in the 10 guilds noted above. Also, any individual that could not be identified to guild was excluded from our analyses. We also recorded the number of individuals of each guild observed during a survey. We conducted our surveys over 104 weeks to reduce potential bias associated with sample size and observer visitation rate, weather events, and variability in guild-specific populations and movements. However, no observations were made during the week of November 23, 2009, due to logistical constraints. Therefore, we completed an additional week of surveys for this set of impoundments (set $\mathrm{A}$ ) at the end of that observational period to maintain an equal number of observations between all four subsets of impoundments.

\subsection{Model development}

Based in part on models tested by Blackwell et al. (2008) and parameters examined in prior research (Table 1 ), we developed a set of eight a priori models to describe impoundment use by each avian guild, as well as a null model (intercept only). Specifically, we defined guild "use" of an impoundment in terms of whether the guild was detected or not over a minimum number of weeks, given our sampling protocol and adjustments to initial counts (see Section 2.5). We tested each model, except the null model, with and without the effect of seasonal parameters, resulting in a set of 17 models (Table 2) applied to observations for each avian guild. Our models reflected a broad concentration on site-specific and local-level parameters, as well as reduced models composed of parameters of both categories (Table 2).

As to specific model parameters, we based our estimate of impoundment area on the mean of six surface-area measurements (ha) made once every five weeks, beginning the first full week of field observations (see Section 2.3). We used TDS Nomad ${ }^{\circledR}$ GPS 
Table 2

Seventeen a priori models developed to describe use of 40 stormwater impoundments in the Auburn-Opelika Metropolitan area, Lee County, AL, USA, by avian guilds recognized as hazardous to aviation safety (DeVault et al., 2011). Models are presented first in decreasing order of parameter content and, second, with and without seasonal parameters. The impoundments were surveyed from March 2008 through 2010.

\begin{tabular}{ll}
\hline No./model $^{\mathrm{a}, \mathrm{b}}$ & $K^{\mathrm{c}}$ \\
\hline 1. INT AREA IRREG OW:EV SLOPE VEG SPR SUM FALL PRECIP & 11 \\
2. INT AREA IRREG OW:EV SLOPE VEG PRECIP & 8 \\
3. INT AREA IRREG OW:EV ISOL SPR SUM FALL PRECIP & 10 \\
4. INT AREA IRREG OW:EV ISOL PRECIP & 7 \\
5. INT TYPE IRREG SLOPE VEG SPR SUM FALL PRECIP & 10 \\
6. INT TYPE IRREG SLOPE VEG PRECIP & 7 \\
7. INT TYPE SLOPE VEG SPR SUM FALL PRECIP & 9 \\
8. INT TYPE SLOPE VEG PRECIP & 6 \\
9. INT AREA OW ISOL SPR SUM FALL PRECIP & 9 \\
10. INT AREA OW ISOL PRECIP & 6 \\
11. INT AREA LAND SPR SUM FALL PRECIP & 8 \\
12. INT AREA LAND PRECIP & 5 \\
13. INT ISOL IRREG SPR SUM FALL PRECIP & 8 \\
14. INT ISOL IRREG PRECIP & 5 \\
15. INT IRREG VEG SPR SUM FALL PRECIP & 8 \\
16. INT IRREG VEG PRECIP & 5 \\
17. INT PRECIP & 3 \\
\hline
\end{tabular}

a Model parameters: INT $=$ model intercept $\left(\beta_{0}\right)$; TYPE $=$ basin design (retention vs. detention; $A R E A=$ mean impoundment surface area; $I R R E G=$ mean perimeter irregularity of impoundment surface area; $\mathrm{OW}: \mathrm{EV}=$ mean ratio of open water to emergent vegetation; $\mathrm{OW}=$ total area of open water resources within $1 \mathrm{~km}$ of an impoundment; $I S O L=$ minimum distance from an impoundment to the nearest open water resource; SLOPE = mean impoundment bank slope; VEG=vegetation diversity index; LAND = landscape diversity index; season =SPR, SUM, and FALL; PRECIP = precipitation. See text for further detail.

b Our definition of TYPE differed slightly from the intended design (e.g., Baier et al., 2003 ) because certain impoundments designed as detention ponds retained water continuously during the study period, likely due to the accumulation of sediment in drain pipes.

c Number of model parameters, including intercept and error.

coupled with a Hemishpere Crescent ${ }^{\circledR}$ backpack-mounted antenna operating the GIS package SOLOForest ${ }^{\circledR}$, to trace the shoreline perimeter of each site, from which the area value was calculated. We also calculated shoreline irregularity as the ratio of the mean impoundment perimeter to the perimeter of a perfect circle of the same area (see Table 1). Further, we visually estimated the percentage of total impoundment surface area which was dominated by emergent vegetation. From this measure of percent cover, we calculated the average ratio of open water to emergent vegetation across all six surface-area measurements made every five weeks. In addition, we measured percent slope of an impoundment ( $\mathrm{m}$ of vertical drop/m of horizontal run) by using a Haglof ${ }^{\circledR}$ digital clinometer. We calculated bank slope (Table 1) as the mean percent slope for the cardinal points at the waterline of each impoundment.

Further, at each impoundment we defined vegetation guilds as bare rock, bare soil, detritus, archaic plants (e.g., bryophytes, Pteridophyta sp., Marchantiophyta sp., and Cycadophyta sp.), grasses and forbes, monoculture turfgrasses, shrubs/seedling trees, sapling trees of diameter-at-breast-height $<25.4 \mathrm{~cm}$., mature trees, aquatic plants (Lemnaceae, Nymphaeaceae, Equisetum sp., Typha sp., as well as Poaceae, Cyperaceae, and Juncaceae that favor hydric soils. We also included aquatic trees (e.g., Cupressaceae). We surveyed an area of the impoundment basin encompassing a buffer extending $5 \mathrm{~m}$ into the impoundment and $5 \mathrm{~m}$ away from the shoreline. We recorded the coverage of each vegetation guild as a percent of the total buffer area. We then incorporated our vegetation guilds in an index of vegetation diversity for each impoundment by calculating a Shannon Diversity Index, $D$ (Ricklefs, 1990) of vegetation at the midpoint of both observational years (August 2008 and 2009) as

$D=-\Sigma_{i=1}^{S} p_{i} \ln p_{i}$ where, $S$ is the number of vegetation guilds present at each impoundment and $p_{i}$ is the area of each guild as a proportion of the total buffer area.

We used the vegetation diversity index values calculated in 2008 for all sampling periods that began in March 2008 to February 2009. We used the index calculated in 2009 for sampling periods which began from March 2009 to March 2010. This process more accurately reflected the nature of vegetation community diversity at impoundments over time, because some impoundments experienced significant shifts in vegetation community composition during the observation period attributed to management efforts (i.e., brush removal by landowners).

We manually digitized open-water resources within $1 \mathrm{~km}$ of an impoundment and calculated their total area (Table 1) using ArcMap 9.2 (Environmental Systems Research Institute, Redlands, CA, USA) on digital orthorectified quarter quadrangle aerial images (Alabama State Water Program; http://www.aces.edu/waterquality/gis_data/index.php). Impoundment isolation (Table 1) was recorded as the minimum distance between each impoundment and any open-water resource, as calculated using the Near tool in ArcMap 9.2. We scaled both the open water and isolation metrics by dividing each by 10 , thus adjusting them to the same order of magnitude as the other parameters used in the analysis.

We developed an index for land-use diversity within $1 \mathrm{~km}$ of each impoundment (Table 1) using data from the Alabama Gap Analysis Project (http://www.auburn.edu/academic/forestry_ wildlife/alabama_gap_analysis_project/index.php). We modified the AL-Gap data set by condensing the habitat types represented in the study area into six broad land-use categories: open water, open development (containing <20\% impervious surface and including golf courses, rural homes, row crops and pastures), low-(20-49\% impervious surface), medium-(50-79\%; impervious surface), high-intensity development (80-100\% impervious surface), and undeveloped. We estimated the percent coverage for each land-use category in the $1-\mathrm{km}$ radius around each impoundment, and then calculated a Shannon Diversity Index of land-use (see previous equation, above) where $S$ is the number of categories present within $1 \mathrm{~km}$ of each impoundment and $p_{i}$ is the area of each guild as a proportion of the total buffer area.

In addition, we categorized seasonal parameters as reflecting observations made during March through May (spring), June through August (summer), September through November (fall); and December through February (winter). Finally, effects on detection (MacKenzie, 2005) because of precipitation can influence estimates of avian abundance or site use; thus, we recorded precipitation amounts weekly. Precipitation data (PRECIP) were drawn from the National Oceanic and Atmospheric Administration's (NOAA) National Climatic Data Center (NOAA National Climactic Data Center, http://www.ncdc.noaa.gov/oa/ncdc.htm).

\subsection{Analysis}

We converted weekly count data from each impoundment to binary values (detected or not detected). If a guild was observed at least once during a weekly survey, that guild was assigned as detected for that specific impoundment for that weekly interval. In this manner we avoided confounding issues associated with lack of independence among individuals or flocks. Further, although we had no a priori requirement for number of individuals present before assigning a guild as detected, our modeling approach was conservative with regard to number of detections required (see below). 
Table 3

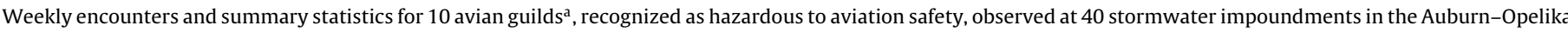

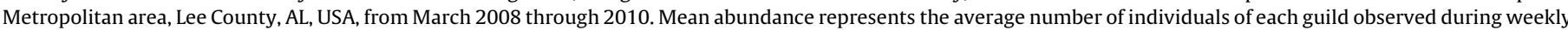
surveys conducted at impoundments every four weeks over 104 weeks (see text for further details).

\begin{tabular}{|c|c|c|c|c|c|}
\hline Guild (no. sp) $)^{b}$ & Detected $^{c}$ & Mean weekly abundance & SE weekly abundance & Maximum mean weekly count ${ }^{\mathrm{a}}$ & No. sites \\
\hline Geese (2) & 68 & 0.5 & 1.7 & 29.7 & 12 \\
\hline Blackbirds (9) & 361 & 2.7 & 4.4 & 400.0 & 36 \\
\hline Dabbling ducks (5) & 111 & 0.7 & 2.2 & 43.4 & 14 \\
\hline Diving ducks (9) & 13 & 0.1 & 0.4 & 24.1 & 7 \\
\hline D/E waterfowl (2) & 70 & 1.8 & 8.0 & 71.3 & 5 \\
\hline Doves (4) & 209 & 0.5 & 0.4 & 28.0 & 38 \\
\hline Suliformes (1) & 1 & $<0.0$ & $<0.0$ & 1.2 & 1 \\
\hline Raptors (6) & 41 & 0.1 & 0.1 & 10.5 & 23 \\
\hline Shorebirds (7) & 122 & 0.3 & 0.6 & 11.0 & 23 \\
\hline Wading birds (6) & 210 & 0.2 & 0.2 & 3.7 & 29 \\
\hline
\end{tabular}

a Guilds were arranged primarily by foraging ecology (DeGraaf et al., 1985; Sibley, 2001) and with respect to each species' relative hazard to aviation (DeVault et al., 2011).

b Number of species (see Appendix B) detected per guild.

c Number of weekly intervals in which a guild was detected across sites.

We estimated probability of impoundment "use" by each guild $(p)$ via logistic regression and relative to the number of detections and parameter estimates, $\beta$, as

$p=\frac{1}{1+e^{-\left(\beta_{0}+\cdots \beta_{i}\right)}}$

Because our questions entailed a fairly broad perspective on parameter contribution to species/guild use of impoundments, as opposed to discerning how these parameters might contribute to species behavior (e.g., foraging and breeding), we opted for a generalized linear model structure. We expressed these initial parameter estimates as

$\operatorname{logit}(p)=\log _{e}\left(\frac{p}{1-p}\right)$ (Burnham\&Anderson, 2002).

Below 20 weeks of detection of a guild at least one site, probability of impoundment use by a specific guild was either not estimable or the variance about parameter estimates was substantially greater than the estimate. For guilds observed $\geq 20$ weeks, we calculated Akaike's Information Criterion corrected for sample size, model weights, and associated evidence ratios (Anderson, Burnham, \& Thompson, 2000; Burnham \& Anderson, 2002). We considered models with evidence ratios $<3$ as indistinguishable (Burnham \& Anderson, 2002). We used Matlab ${ }^{\circledR}$ for model fitting (Mathworks, Inc., Matlab ${ }^{\circledR}$ and Simulink ${ }^{\circledR}$ Student Version 7.10.0.499, 2010, Natick, MA).

\section{Results}

\subsection{General findings}

Across the 104 weeks of surveys, 29 impoundments retained water continuously and were considered as retention ponds In contrast, the other 11 impoundments dried completely at least once and were, therefore, considered detention ponds. Our impoundments were on average (SE) 0.41 ha (0.64ha), ranging 0.003 ha to 2.8 ha. Those sites classified as retention ponds averaged 0.56 ha $(0.70 \mathrm{ha})$ and ranged from 0.04 ha to 2.8 ha. Detention ponds were $95 \%$ smaller than retention ponds, averaging $0.03 \mathrm{ha}(0.03 \mathrm{ha}$ ) and ranging $0.003 \mathrm{ha}$ to $0.090 \mathrm{ha}$. Across impoundments, bank slope averaged 41\% (17\%) and ranged $17 \%$ to vertical, the ratio of open water to emergent vegetation was intermediate $(\bar{X} \%$ open water:\% emergent vegetation $=0.48, \mathrm{SE}=0.75$, range $=0.00-3.40)$, perimeters were irregular $(\bar{X}$ irregularity $=1.41, \mathrm{SE}=0.27$, range $=0.70-2.10)$, and isolation was minimal $(\bar{X}$ distance to water resource $=0.35 \mathrm{~km}$, $\mathrm{SE}=0.35 \mathrm{~km}$, range $=0.02-1.47 \mathrm{~km}$ ). Vegetation diversity was low ( $\bar{X}$ index $=1.09, \mathrm{SE}=0.37$; range $=0.10-1.68$; approximately), as was land-use diversity $(\bar{X}$ index $=1.13, S E=0.27$, range $=0.50-1.57)$. Total area of surface water within $1 \mathrm{~km}$ of an impoundment averaged 7.9 ha ( 4.5 ha) and ranged 0.0 ha to 20.2 ha. Weekly precipitation for the study area averaged $127 \mathrm{~mm}(\mathrm{SD}=157 \mathrm{~mm})$. Extreme observations for precipitation were recorded in August 2008 when

\section{Table 4}

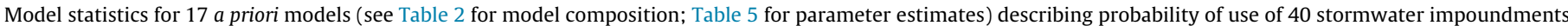

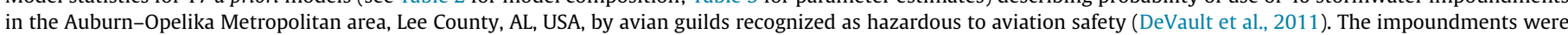

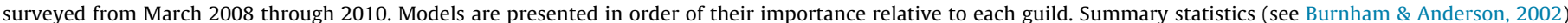

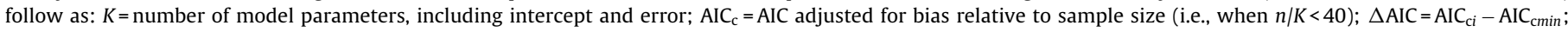
$L=$ model likelihood; AIC weights (relative likelihood), $w_{i}=\exp \left(-1 / 2 \Delta_{i}\right) / \sum_{\gamma=1}^{R} \exp \left(-1 / 2 \Delta_{\gamma}\right)$; evidence ratios (ER) $=$ AIC weight for best-approximating model/wi

\begin{tabular}{|c|c|c|c|c|c|c|c|}
\hline \multirow[t]{2}{*}{ Guild $^{\mathrm{a}}$} & \multirow[t]{2}{*}{ Model } & \multicolumn{6}{|c|}{ Model statistics } \\
\hline & & $K$ & AICc & $\Delta \mathrm{AIC}_{\mathrm{c}}$ & $L$ & $w_{i}$ & ER \\
\hline Geese & 4 & 7 & 237.77 & 0.00 & 1.000 & 0.924 & 1.0 \\
\hline Blackbirds & 5 & 10 & 1076.06 & 0.00 & 1.000 & 0.754 & 1.0 \\
\hline \multirow[t]{2}{*}{ Dabbling ducks } & 2 & 8 & 397.08 & 0.23 & 0.889 & 0.271 & 1.1 \\
\hline & 1 & 11 & 398.23 & 1.39 & 0.499 & 0.152 & 1.8 \\
\hline D/E waterfowl & 4 & 7 & 269.17 & 0.00 & 1.000 & 0.691 & 1.0 \\
\hline \multirow[t]{2}{*}{ Doves } & 5 & 10 & 954.17 & 0.00 & 1.000 & 0.385 & 1.0 \\
\hline & 1 & 11 & 954.32 & 0.15 & 0.926 & 0.357 & 1.1 \\
\hline \multirow[t]{2}{*}{ Raptors } & 2 & 8 & 320.65 & 0.00 & 1.000 & 0.504 & 1.0 \\
\hline & 4 & 7 & 321.17 & 0.52 & 0.772 & 0.389 & 1.3 \\
\hline Shorebirds & 1 & 11 & 556.93 & 0.00 & 1.000 & 0.775 & 1.0 \\
\hline Wading birds & 3 & 10 & 764.99 & 0.00 & 1.000 & 0.618 & 1.0 \\
\hline
\end{tabular}

a With the exception of diving ducks, all guilds were detected at least 20 times (see text, Section 2.5). A single species of Suliforme, Anhinga, was detected once. 
tropical storm, Fay, passed across the southeastern United States (http://www.nhc.noaa.gov/pdf/TCR-AL062008_Fay.pdf).

We observed one to nine species per guild among the 10 guilds considered as hazardous to aviation safety. On average we observed four bird species per week across all impoundments, with weekly species counts ranging from 0 to 16 . However, representatives from only 8 of the 10 guilds were detected over at least 20 weeks, and those guilds were, therefore, included in our analysis (Table 3; Appendix B). Bird use of impoundments reached its minimum in winter and peaked in summer. Detections per guild during winter were too few for parameter estimation, as were detections of diving ducks and Suliformes (Table 3).

We found that impoundment use by the remaining eight guilds was characterized by one to four models, with combined relative likelihoods ranging from approximately $42 \%$ to $>92 \%$ (Table 4). Across guilds, models considered as poor relative to best-approximating models had weights ranging from 0.027 to 0.182 . Impoundment irregularity (generally positively correlated with probability of use) appeared in best-approximating models for eight guilds, followed by area (positively correlated with use across guilds) and the ratio of open water to emergent vegetation, both of which composed best-approximating models for six guilds (Table 5). With the exception of wading birds, precipitation was negatively correlated with probability of impoundment use (Table 5), an indicator that detection was affected by weather conditions.

As for our predictions regarding specific parameters, impoundment type was negatively correlated with use (representing detention ponds), and composed a best-approximating model for blackbirds only (Table 5). Bank slope composed bestapproximating models for four guilds, and was negatively correlated with use in each case (Table 5). Further, vegetation diversity was positively correlated with probability of use by four guilds (Table 5); but, again, this diversity index was relatively low (Table 2). Impoundment isolation was negatively correlated with use for three guilds. Finally, land-use diversity did not contribute to a best-approximating model (Table 5).

\subsection{Guild-specific models}

Relative to individual guilds, we first report findings for impoundment use characterized by single models, then follow with those guilds for which competing models were indicated and in order of relative likelihood.

Impoundment use by geese and domestic/exotic (D/E) waterfowl was best predicted by the same model, and single best-approximating models prevailed for blackbirds, shorebirds, and wading birds, respectively (Tables 4 and 5). Unlike other guilds for which single best-approximating models were identified, impoundment type (detention pond) and bank slope were both negatively correlated with blackbird use, and probability of use was strongly and positively correlated with observations made during spring and summer (Table 5).

Two models were indistinguishable in fit for impoundment use by raptors, representing approximately $89 \%$ of the relative likelihood of raptor use (Table 4). Raptor use was best approximated by a model composed of impoundment area, irregularity, and the ratio of open water to emergent vegetation; impoundment area represented a relatively strong positive effect on use by raptors, but remained highly variable (Table 5 ).

Two models were indistinguishable in fit for doves, representing a relative likelihood of use of $>74 \%$ (Table 4 ). The most parsimonious model for doves comprised irregularity, bank slope, vegetation diversity, and seasonal factors (Table 5).

We found two models indistinguishable in fit for impoundment use by dabbling ducks, but with a combined relative likelihood only of about $42 \%$ (Table 4). Again, area, irregularity, and the ratio of open water to emergent vegetation composed the most parsimonious model, as did bank slope and vegetation diversity (Table 5). Further, bank slope exhibited a particularly strong, negatively correlated effect on probability of use (Table 5). However, weak model evidence (Table 4) between the two best-approximating models suggests that dabbling ducks were possibly responding to factors not measured in this study.

\section{Discussion}

Our findings indicate that broad reduction in use of stormwater impoundments, located within or near airport siting criteria, by bird species hazardous to aviation can be achieved via designs which minimize perimeter, surface area, and the ratio of open water to emergent vegetation (incorporated in designs via use of synthetic liners and access points for efficient removal of sediment). We discuss our findings from the perspective of parameters that were common to best-approximating models for the guilds considered. We also comment on our specific predictions regarding the effects of impoundment type, bank slope, vegetation diversity, and local land-use diversity on probability of use, as well as the possible influence of factors untested in this study. We then relate our findings to design considerations for future stormwater impoundments to be located on and near airports.

\subsection{Common parameters}

Perimeter irregularity, area, and the ratio of open water to emergent vegetation contributed to best-approximating models for 6 to 8 of the 10 avian guilds considered and, with the exception of seasonal parameters, are tied directly to the impoundment design and maintenance, as opposed to local- or landscape-level factors. For example, enhanced cover available to both vertebrate and invertebrate prey species is characteristic of an impoundment whose perimeter is irregular. As such, these impoundments offer increased foraging opportunities to predators (e.g., see Gibbs, Longcore, McAuley, \& Ringelman, 1991; Fairbairn \& Dinsmore, 2001). Also, in natural wetland systems, variation in avian species richness has been shown to relate to marsh area and the area of nearby marsh complexes (Brown \& Dinsmore, 1986). Similarly, impoundment area was identified in several studies as influential to bird use (e.g., Adams et al., 1985; Blackwell et al., 2008; Brown \& Dinsmore, 1986; Carbaugh, Combs, \& Dunton, 2010). Further, there is a positive association of impoundment area with aquatic vegetation for forage and production of macroinvertebrates, factors important to waterfowl (Bates, Valentine, \& Sprague, 1988).

Dykstra, Hays, Daniel, and Simon (2001) suggested that anthropogenic water resources are an important component of suburban red-shouldered hawk (Buteo lineatus) habitat, whereas Stout, Temple, and Cary (2006) demonstrated that open water was a small and negatively correlated component of occupied red-tailed hawk (Buteo jamaicensis) habitat in a similar suburban setting. Dykstra et al. (2001) also suggested that constructed-pond and -wetlands allowed suburban-dwelling red-shouldered hawks to sustain themselves on smaller territories (than in less developed areas) by providing additional foraging sites. Our findings lend support to those of Dykstra et al. (2001), but also indicate a balance between potential prey habitats and cover resources that could decrease prey availability (e.g., see Baker \& Brooks, 1981; Bechard, 1982; Preston, 1990). Specifically, we found that impoundment area had a strong, positive correlation with use by diurnal raptors, whereas increasing the ratio of open water to emergent vegetation exerted a negative effect on use (Table 5). 
Table 5

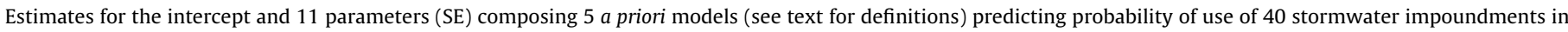

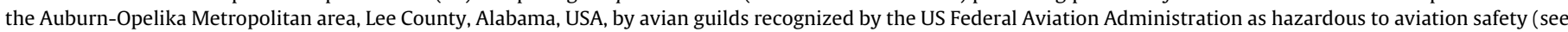

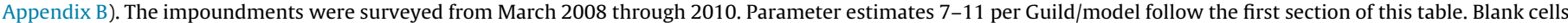
indicate that the parameter was not a model component. See Table 1 for parameter definitions and Table 4 for summary statistics.

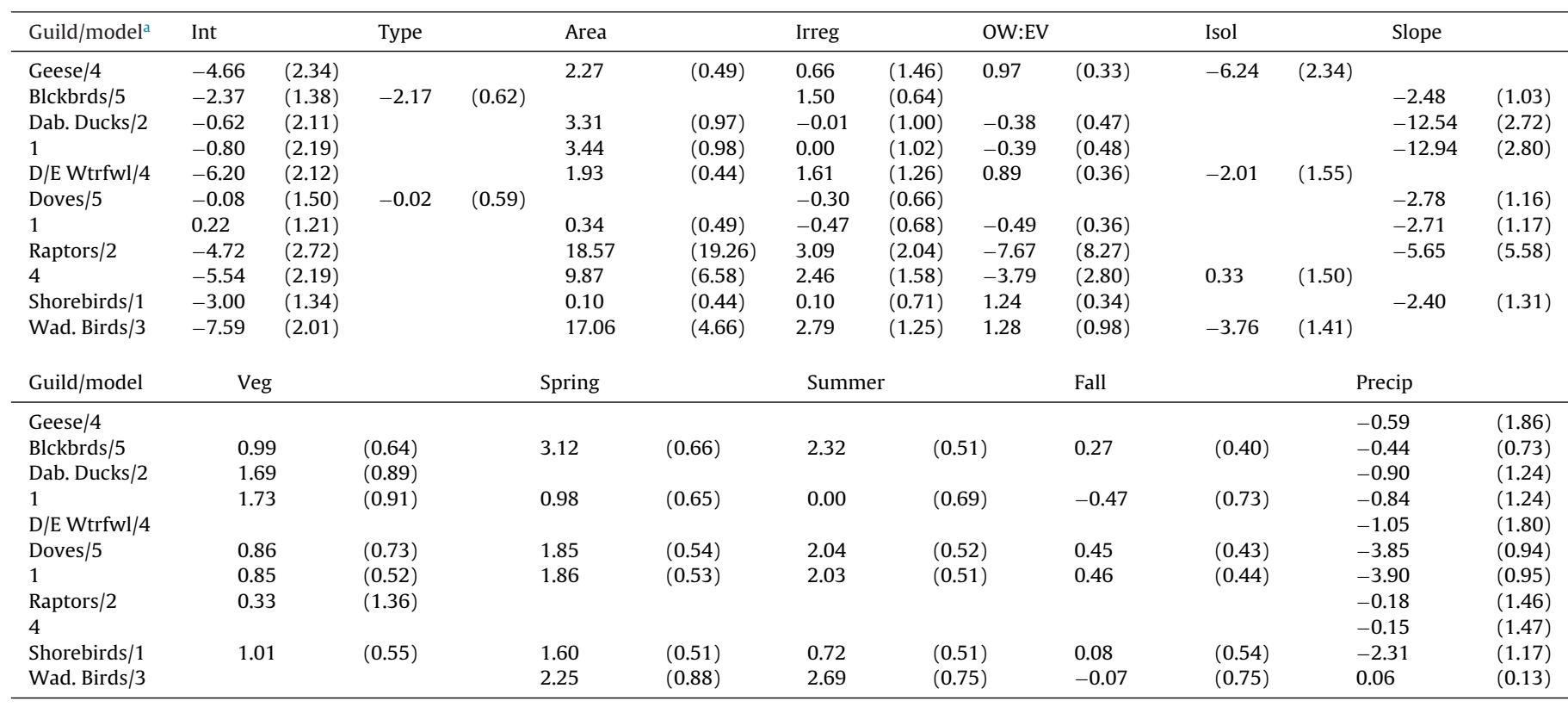

a See Table 2 relative to model number and composition.

The composition of a wetland with regard to coverage by emergent vegetation also influences avian use. Specifically, the ratio of the percent of open water to emergent vegetation is positively correlated with waterfowl use of wetland resources (Blackwell et al., 2008; Duffield, 1986; Hobaugh \& Teer, 1981; Weller \& Spatcher, 1965), and wetlands with an intermediate level of emergent cover (e.g., 33-66\%) have been shown to host greater avian species richness (Belánger \& Courture, 1988; Creighton, Sayler, Tabor, \& Monda, 1997; Fairbairn \& Dinsmore, 2001; Gibbs et al., 1991).

Seasonal parameters, which appeared in best-approximating models for four guilds, can contribute to impoundment use via associated fluctuations in avian populations during spring and fall migrations. In fact, seasonal trends reflecting migration and the increase in population sizes with young-of-the-year are evident in bird strikes reported to the FAA National Wildlife Strike Database (see Dolbeer, 2011; http://wildlife-mitigation.tc.faa.gov/wildlife/). In addition, our finding that "summer" exhibited a strong, positive effect on blackbird use of impoundments (Table 5) indicates the likely importance of these sites as water resources to local populations. However, the paucity of observations during winter for the ten guilds should not be construed as necessarily a decreased attraction of birds to impoundments. On the contrary, this caveat is an artifact of the sample requirement of our models for parameter estimation. For example, seasonal effects were not evident in our results for geese, dabbling ducks, and D/E waterfowl (Table 5).

Bank slope, contributing to best-approximating models for four guilds, is generally negatively correlated with site use by Canada geese (Branta canadensis) and other geese (see Dunton \& Combs, 2010 and references therein), but was not a factor in our bestapproximating model for geese or D/E waterfowl (Table 5). In contrast, bank slope had a comparably strong and negative influence on site use by dabbling ducks and a moderate, negative effect on use by shorebirds (Table 3 ). We note that our sites were likely too gradual in slope, approximately $42 \%$ ( $m$ of vertical drop $/ m$ of horizontal run), to affect site selection by geese, but sufficient to affect use by smaller waterfowl (see McKinstry \& Anderson, 2002).
For example, some suggest that for shorebird conservation, bank slopes in restored wetlands should not exceed $10 \%$ to $20 \%$ (Engilis \& Reid, 1996). Visual obstruction due to bank slope could also affect perceived risk of predation in some species (e.g., see Blackwell et al., 2013).

\subsection{Less important parameters}

Higher values for vegetation diversity within the impoundment basin, a parameter which appeared in models for four guilds (Table 5), are associated with potential cover, loafing, and foraging alternatives, and thus increased avian use (Bancroft, Gawlik, \& Rutchey, 2002; Cicero, 1989; Steen, Gibbs, \& Timmermans, 2006). For example, avian richness and abundance along riparian areas have been linked to edge vegetation diversity (LaRue, Belánger, \& Huot, 1995). Specifically, these authors defined edge effect in the context of density and number of plant species occurring as a result of the juxtaposition of a forest stand, an aquatic ecosystem, and a shrub-grass wetland. Similarly, but in the context of playa wetlands, Smith, Haukos, \& Prather (2004) speculated that avian diversity, as well as the abundance of some species, is linked to edge and habitat diversity. However, in our study vegetation diversity scored relatively low, evidenced by the fact that turfgrasses were predominant, composing on average $25-36 \%$ of the vegetation guilds per site.

Impoundment isolation and the area of adjacent wetlands also correlate (negatively and positively, respectively) with avian use of wetland resources (Brown \& Dinsmore, 1986; Blackwell et al., 2008; Duffield, 1986; Dunton \& Combs, 2010). Also, although avian species richness is related to proximity of wetlands (sites within $5 \mathrm{~km}$ ) of 20 ha to 30 ha (Brown \& Dinsmore, 1986), even smaller wetland complexes (e.g., 0.4 ha; comparable to sites in our study) can be important (Gibbs, 1993, 2000). Further, we note that Paracuellos and Telleria (2004) linked this metric, as well as the development of emergent vegetation, to avian species richness, including dabbling and diving ducks and the Rallidae. 
However, isolation appeared in best-approximating models for only three guilds (Table 5) and we found on average approximately 8 ha of water resources within $1 \mathrm{~km}$ of each site. Despite contributing to models for geese, D/E waterfowl, and wading birds (Table 5), the absence of this parameter from models for dabbling might be related to overall resource availability. Specifically, precipitation for Alabama from March 2008 through 2010 was approximately $7 \%$ above the state's long-term average (see http://www.ncdc.noaa.gov/temp-and-precip/time-series/). We suggest that the elevated levels of precipitation over the study period served to diminish the potential effect in our models of neighboring open-water resources (Table 5), as well as replenish water within the 11 ponds defined as detention ponds. In contrast, Blackwell et al. (2008) found opposite effects of isolation on site use by duck guilds, and suggested that drought conditions concentrated dabbling ducks on sparse resources, whereas impoundment use by diving ducks, species likely making longer flights from larger bodies of water, was negatively correlated.

We note, also, that an increase in land-use diversity has been observed to benefit some avian species groups (Blair, 1996; Dykstra et al., 2001; Stout et al., 2006; Traut and Hostetler, 2003). However, as in the case of vegetation diversity, the value of this metric was relatively low (Table 2), and it did not contribute to a best-approximating model. We suggest, however, that inclusion of housing density and canopy cover might improve parameter performance, as these metrics have been used to describe avian community assemblages (MacGregor-Fors, 2008; Pidgeon et al., 2007), as well as rodent communities (Cavia, Cueto, \& Suárez, 2009).

\subsection{Untested factors}

Dieter, Anderson, Gleason, Mammenga, \& Vaa (2010) demonstrated that fall movement of Canada geese was influenced by hunting pressure in South Dakota, USA, while Holevinski, Curtis, and Malecki (2007) reported that suburban-dwelling Canada geese demonstrated high-site fidelity in areas closed to hunting, despite hazing efforts. To our knowledge there was no waterfowl hunting in the study area during the observation period, and we rarely encountered predators that might prey upon or harass waterfowl (e.g., domestic cats Felis catus). It is, therefore, plausible that stormwater impoundments in this urban area offer geese and other waterfowl a refuge from predation and abundant anthropogenic resources (i.e., palatable turfgrasses).

We recognize, however, that the relative likelihoods for our best-approximating models (Table 4) were likely influenced, in part, by our use of guilds versus individual species. Still, we consider our approach robust from the perspective of offering design recommendations for impoundments to reduce use by suites of birds recognized as hazardous to aviation safety. In addition, we contend that models developed for avian guilds likely reduced potential problems associated with lack of independence among observations. Specifically, focusing on impoundment use by individual species, only, could introduce bias in an evaluation of effects of site characteristics on avian use because of concurrent use by congeners or other closely related species that might serve as attractants.

\subsection{Recommendations}

We suggest that broad reduction in use of stormwater impoundments, located within or near airport siting criteria, by bird species recognized as hazardous to aviation can be achieved via designs which minimize perimeter, surface area, and the ratio of open water to emergent vegetation across seasons. However, differences in bird-habitat associations between foraging guilds represented in this study underscore the complex challenge faced by urban planners and airport managers in addressing bird-strike hazards from multiple avian guilds. Property owners with land bordering airports and managers of those airports must realize that application of design recommendations to deter one guild may inadvertently encourage impoundment use by another guild. Alternatively, designs are available by which stormwater is infiltrated and stored below ground, thus removing the resource as a wildlife attractant (see Higgins \& Liner, 2007).

\section{Acknowledgments}

Funding for this study was provided via Interagency Agreement 07-7201-4430-GR between the FAA and US Department of Agriculture, Animal and Plant Health Inspection Service (USDA/APHIS), Wildlife Services (WS) Alabama office. With the exception of BJF and $\mathrm{WBH}$, author salaries were provided by their respective institutions. We thank T. Steury (Auburn University), M. MacKenzie (Auburn University; deceased), M. Dunn (Auburn Water Works Board), J. B. Grand (US Geological Survey, Alabama Cooperative Fish and Wildlife Research Unit), L. Simpson (City of Auburn Business Development Services), and J. A. Schmidt (USDA/APHIS/WS National Wildlife Research Center, NWRC) for their technical and logistical assistance. T. L. DeVault, A. B. Franklin (NWRC), and M. Stapanian (US Geological Survey) reviewed earlier versions of this manuscript.

\section{Appendix A.}

We used a Geographic information system (GIS) to estimate the extent of aquatic landcover at a sample of 49 airports. We randomly selected $10 \%$ of certificated airports located within each of eight Omernik Level I ecological regions (Omernik, 1987) in the contiguous U.S. Two ecoregions were excluded because of their small size $(0.28 \%$ and $0.55 \%$ of the contiguous U.S.) and scarcity of certificated airports. We used the GIS to extract aquatic landcover polygons from 2007-2009 true-color digital orthoimagery with 1-m resolution obtained from the National Agriculture Imagery Program (NAIP). We defined aquatic land cover as any point where water covered the land at the instant the remotely-sensed data were collected. For our extraction protocol, we used all three available spectral bands as well as band 3 used as a texture band, a resample factor of two, a Manhattan 9 input representation, a minimum object size of 250 pixels, and included instances of rotated features.

We assessed the accuracy of our aquatic extractions by placing 100 random points on each of four airport classification maps, split evenly between aquatic and non-aquatic cover types, and then determined whether points were classified correctly. Overall accuracy was $98 \%$ (393 of 400 points were classified correctly). The kappa coefficient, a measure of agreement between the extraction classification and the reference data, was 0.96, indicating almost perfect agreement (Landis \& Koch, 1977). The producer's accuracy (probability of a reference point being correctly classified) was 97.5\% and 99\% for aquatic and non-aquatic cover types, respectively; the user's accuracy (probability that a point classified in the extraction represents the correct landcover type) was 99\% and 97.5\% for aquatic and non-aquatic cover types, respectively. GIS analyses were conducted using ArcMap ver. 9.3 (Environmental Systems Research Institute, Redlands, CA, USA), Feature Analyst for ArcGIS ver. 4.2 (Overwatch Systems, LTD, Missoula, MT, USA), and Hawth's Analysis Tools ver. 3.27 (Beyer, 2004).

We thank J. A. Schmidt (US Department of Agriculture, Animal and Plant Health Inspection Service, Wildlife Services' National Wildlife Research Center) for his assistance with these analyses. 


\section{Appendix B.}

Bird species observed using 40 stormwater impoundments in the Auburn-Opelika Metropolitan area, Lee County, AL, USA, from March 2008 through 2010. Species are arranged alphabetically by common name (Alabama Ornithological Society, 2006). Species were assigned to foraging guilds as per (DeGraaf et al., 1985; Sibley, 2001) and potential hazard posed to aviation safety (Dolbeer, 2011).

\begin{tabular}{|c|c|c|}
\hline Common name & Genus and species & Foraging guild \\
\hline American black duck & Anas rubripes & Dabbling ducks \\
\hline American kestrel & Falco sparverius & Raptors \\
\hline Anhinga & Anhinga anhinga & Suliformes \\
\hline Black vulture & Coragyps atratus & Raptors \\
\hline Black-crowned night heron & Nycticorax nycticorax & Wading birds \\
\hline Blue-winged teal & Anas discors & Diving ducks \\
\hline Bobolink & Dolichonyx oryzivorus & Blackbirds \\
\hline Brewer's blackbird & Euphagus cyanocephalus & Blackbirds \\
\hline Broad-winged hawk & Buteo platypterus & Raptors \\
\hline Brown-headed cowbird & Molothrus ater & Blackbirds \\
\hline Bufflehead & Bucephala albeola & Diving ducks \\
\hline Canada goose & Branta canadensis & Geese \\
\hline Common grackle & Quiscalus quiscula & Blackbirds \\
\hline Common ground-dove & Columbina passerina & Doves \\
\hline Cooper's hawk & Accipiter cooperii & Raptors \\
\hline Domestic duck & Anas sp. & D/E waterfowl \\
\hline Domestic goose & Anser sp. & $\mathrm{D} / \mathrm{E}$ waterfowl \\
\hline Eastern meadowlark & Sturnella magna & Blackbirds \\
\hline Eurasian collared dove & Streptopelia decaocto & Doves \\
\hline European starling & Sturnus vulgaris & Blackbirds \\
\hline Common goldeneye & Bucephala clangula & Diving ducks \\
\hline Great blue Heron & Ardea herodias & Wading bird \\
\hline Great egret & Ardea alba & Wading bird \\
\hline Greater scaup & Aythya marila & Dabbling ducks \\
\hline Green heron & Butorides virescens & Wading birds \\
\hline Hooded merganser & Lophodytes cucullatus & Diving ducks \\
\hline Killdeer & Charadrius vociferus & Shorebirds \\
\hline Laughing gull & Larus atricilla & Shorebirds \\
\hline Least sandpiper & Calidris minutilla & Shorebirds \\
\hline Lesser scaup & Aythya affinis & Diving ducks \\
\hline Little blue heron & Egretta caerulea & Wading birds \\
\hline Mallard & Anas platyrhynchos & Dabbling ducks \\
\hline Mourning dove & Zenaida macroura & Doves \\
\hline Northern shoveler & Anas clypeata & Dabbling ducks \\
\hline Orchard oriole & Icterus spurius & Blackbirds \\
\hline Pied-billed grebe & Podilymbus podiceps & Grebes \\
\hline Red-breasted merganser & Mergus serrator & Diving ducks \\
\hline Redhead & Aythya americana & Diving ducks \\
\hline Red-shouldered hawk & Buteo lineatus & Raptors \\
\hline Red-tailed hawk & Buteo jamaicensis & Raptors \\
\hline Red-winged blackbird & Agelaius phoeniceus & Blackbird \\
\hline Ring-billed gull & Larus delawarensis & Shorebirds \\
\hline Ring-necked duck & Aythya collaris & Diving ducks \\
\hline Rock pigeon & Columba livia & Doves \\
\hline Rusty blackbird & Euphagus carolinus & Blackbirds \\
\hline Semipalmated plover & Charadrius semipalmatus & Shorebirds \\
\hline Snow goose & Chen caerulescens & Geese \\
\hline Snowy egret & Egretta thula & Wading birds \\
\hline Solitary sandpiper & Tringa solitaria & Shorebirds \\
\hline Spotted sandpiper & Actitis macularia & Shorebirds \\
\hline Surf scoter & Melanitta perspicillata & Diving ducks \\
\hline Tricolored heron & Egretta tricolor & Wading birds \\
\hline Turkey vulture & Cathartes aura & Raptors \\
\hline Wood duck & Aix sponsa & Dabbling ducks \\
\hline
\end{tabular}

\section{References}

Adams, L. W., Dove, L. E., \& Franklin, T. M. (1985). Mallard pair and brood use of urban stormwater-control impoundments. Wildlife Society Bulletin, 13, 46-51.

Airport Cooperative Research Program, 2009. Deicing planning guidelines and practices for stormwater management systems. ACRP Report 14. Washington, DC: Transportation Research Board.

Alabama Ornithological Society, Field checklist of Alabama birds, 2006 http://www.bham.net/aos/abrc/AOSChecklist_april2006.pdf
Allan, J. R. (2002). The costs of bird strikes and bird strike prevention. In L. Clark, J. Hone, J. A. Shivik, R. A. Watkins, K. C. Vercauteren, \& J. K. Yoder (Eds.), Human conflicts with wildlife: economic considerations Proceedings of the third NWRC special symposium, (pp. 147-152). Fort Collins, CO: National Wildlife Research Center.

Anderson, D. R., Burnham, K. P., \& Thompson, W. L. (2000). Null hypothesis testing: problems, prevalence, and an alternative. Journal of Wildlife Management, 64, 912-923.

Baker, J. A., \& Brooks, R. J. (1981). Distribution patterns of raptors in relation to density of meadow voles. Condor, 83, 42-47.

Baier, J. H., Holloway, J., Hulcher, R., Logiotatos, T., Johnson, J. L., Norton, E. L., Oakes, P. L., Paglione, T., Rogers, K. M., Smith, B. D., Surrency, E. D., \& Thurmond, J. (2003). Erosion control, sediment control and stormwater management on construction sites and urban areas. Montgommery, AL: Alabama Soil and Water Conservation Committee.

Bancroft, G. T., Gawlik, D. E., \& Rutchey, K. (2002). Distribution of wading birds relative to vegetation and water depths in the northern Everglades of Florida, USA Waterbirds, 25, 265-391.

Bart, J., \& Earnst, S. (2002). Double sampling to estimate density and population trends in birds. Auk, 119, 36-45.

Bates, G., Valentine, G. L., \& Sprague, F. H. (1988). Waterfowl habitat created by floodwater-retarding structures in the southern United States. In M. W. Weller (Ed.), Waterfowl in Winter (pp. 419-426). Minneapolis, MN: University of Minnesota Press.

Bechard, M. J. (1982). Effect of vegetative cover on foraging site selection by Swainson's hawk. Condor, 84, 153-159.

Belánger, L., \& Courture, R. (1988). Use of man-made ponds by dabbling duck broods Journal of Wildlife Management, 52, 718-723.

Beyer, H. L. (2004). Hawth's analysis tools for ArcGIS http://www.spatialecology.com/htools

Blackwell, B. F., DeVault, T. L., Fernández-Juricic, E., \& Dolbeer, R. A. (2009). Wildlife collisions with aircraft: a missing component of land-use planning for airports. Landscape and Urban Planning, 93, 1-9.

Blackwell, B. F., Schafer, L. M., Helon, D. A., \& Linnell, M. A. (2008). Bird use of stormwater-management ponds: decreasing avian attractants on airports. Landscape and Urban Planning, 86, 162-170.

Blackwell, B. F., Seamans, T. W., Schmidt, P. M., DeVault, T. L., Belant, J. L., Whitting ham, M. J., Martin, J. A., \& Fernández-Juricic, E. (2013). A framework for managing airport grasslands and birds amidst conflicting priorities. Ibis, 155, 18-193.

Blair, R. B. (1996). Land use and avian species diversity along an urban gradient. Ecological Applications, 6, 506-519.

Brand, A. B., \& Snodgrass, J. W. (2009). Value of artificial habitats for amphibian reproduction in altered landscapes. Conservation Biology, 24, 295-301.

Brown, M., \& Dinsmore, J. L. (1986). Implications of marsh size and isolation for marsh bird management. Journal of Wildlife Management, 50 392-397.

Burnham, K. P., \& Anderson, D. R. (2002). Model selection and multimodel inferencea practical information - theoretic approach (2nd ed.). New York, NY: Springer.

Carbaugh, J. S., Combs, D. L., \& Dunton, E. M. (2010). Nest-site selection and nesting ecology of giant Canada geese in central Tennessee. Human-Wildlife Interactions, 4, 207-212.

Caula, S., Marty, P., \& Martin, J. L. (2008). Seasonal variation in species composition of an urban bird community in Mediterranean France. Landscape and Urban Planning, 87, 1-9.

Cavia, R., Cueto, G. R., \& Suárez, O. V. (2009). Changes in rodent communities according to the landscape structure in an urban ecosystem. Landscape and Urban Planning, 90, 11-19.

Cicero, C. (1989). Avian community structure in a large urban park: controls of loca richness and diversity. Landscape and Urban Planning, 17, 221-240.

Cleary, E. C., \& Dolbeer, R. A. (2005). Wildlife hazard management at airports (2nd ed.) Washington, DC: Federal Aviation Administration, Office of Airport Safety and Standards, Airport Safety and Compliance Branch.

Commission for Environmental Cooperation. (1997). Ecological regions of North America: towards a common perspective. Montreal: Communications and Public Outreach Department of the CEC Secretariat.

Creighton, J. H., Sayler, R. D., Tabor, J. E., \& Monda, M. J. (1997). Effects of wetland excavation on avian communities in eastern Washington. Wetlands, 17, 216-227.

DeGraaf, R. M., Tilghman, N. G., \& Anderson, S. H. (1985). Foraging guilds of North American birds. Environmental Management, 9, 493-536.

DeVault, T. L., Belant, J. L., Blackwell, B. F., Martin, J. A., Schmidt, J. A., \& Burger, L. W. Jr. (2012). Airports offer unrealized potential for alternative energy production. Environmental Management, 49, 517-522.

DeVault, T. L., Belant, J. L., Blackwell, B. F., \& Seamans, T. W.(2011). Interspecific variation in wildlife hazards to aircraft: implications for airport wildlife management. Wildlife Society Bulletin, 35, 394-402.

Dieter, C. D., Anderson, B. J., Gleason, J. S., Mammenga, P. W., \& Vaa, S. (2010). Late summer movements by giant Canada geese in relation to a September hunting season. Human-Wildlife Interactions, 4, 232-246.

Dolbeer, R. A. (2006). Height distribution of birds as recorded by collisions with civil aircraft. Journal of Wildlife Management, 70, 1345-1350.

Dolbeer, R. A. (2011). Increasing trend of damaging bird strikes with aircraft outside the airport boundary: implications for mitigation measures. Human-Wildlife Interactions, 5, 235-248.

Dolbeer, R. A., Wright, S. E., Weller, J., \& Beiger, M. J. (2012). Wildlife strikes to civil aircraft in the United States, 1990-2011. In Serial Report No. 18. Washington, 
DC: U.S. Department of Transportation, Federal Aviation Administration, Office of Airport Safety and Standards.

Duffield, J. M. (1986). Waterbird use of a urban stormwater wetland system in central California, USA. Colonial Waterbirds, 9, 227-235.

Dunton, E. M., \& Combs, D. L. (2010). Movements, habitat selection, associations and survival of giant Canada goose broods in central Tennessee. Human-Wildife Interactions, 4, 192-201.

Dykstra, C. R., Hays, J. L., Daniel, B., \& Simon, M. (2001). Home range and habitat use of suburban red-shouldered hawks in southwestern Ohio. Wilson Bulletin, 113, 308-316.

Engilis, A., Jr., \& Reid, F. A. (1996). Challenges in wetland restoration of the Great Basin. International Wader Studies, 9, 71-79.

Fairbairn, S. E., \& Dinsmore, J. J. (2001). Local and landscape-level influences on wetland bird communities of the prairie pothole region of Iowa, USA. Wetlands, 21, 41-47.

Flight Safety Foundation (August-November 2000). Flight Safety Foundation approach-and-landing accident reduction briefing note 4.2-energy management. Flight Safety Digest, 75-80. http://flightsafety.org/archives-and-resources/ publications (http://flightsafety.org/files/alar_bn4-2-energymgmt.pdf

Gibbs, J. P. (1993). Importance of small wetlands for the persistence of local populations of wetland-associated animals. Wetlands, 13, 25-31.

Gibbs, J. P. (2000). Wetland loss and biodiversity conservation. Conservation Biology, $13,314-317$.

Gibbs, J. P., Longcore, J. R., McAuley, D. G., \& Ringelman, J. K. (1991). Use of wetland habitats by selected nongame waterbirds in Maine. Fish and wildlife research publication 9. USA: United States Fish and Wildlife Service.

Higgins, J., \& Liner, M. (2007). Engineering runoff solutions. Airport Business, 21, $22-25$.

Hobaugh, W. C., \& Teer, J. G. (1981). Waterfowl use characteristics of floodprevention lakes in north-central Texas. Journal of Wildlife Management, 45, 16-26.

Holevinski, R. A., Curtis, P. D., \& Malecki, R. A. (2007). Hazing of Canada geese is unlikely to reduce nuisance populations in urban and suburban communities. Human-Wildlife Conflicts, 1, 257-264.

Landis, J. R., \& Koch, G. G. (1977). The measurement of observer agreement for categorical data. Biometrics, 33, 159-174.

LaRue, P., Belánger, L., \& Huot, J. (1995). Riparian edge effects on boreal balsam fir bird communities. Canadian Journal of Forest Research, 25, $555-556$.

Le Viol, I., Mocq, J., Julliard, R., \& Kebiriou, C. (2009). The contribution of motorway stormwater retention ponds to the biodiversity of aquatic macroinvertebrates. Biological Conservation, 42, 3163-3171.

MacGregor-Fors, I. (2008). Relation between habitat attributes and bird richness in a western Mexico suburb. Landscape and Urban Planning, 84, 92-98.

MacKenzie, D. (2005). What are the issues with presence-absence data for wildlife managers? Journal of Wildlife Management, 69, 849-860.
Martin, J. A., Belant, J. L., DeVault, T. L., Burger, L. W., Jr., Blackwell, B. F., Riffell, S. K., \& Wang, G. (2011). Wildlife risk to aviation: a multiscale issue requires a multi-scale solution. Human-Wildlife Interactions, 5, 198-203.

McKinstry, M. C., \& Anderson, S. H. (2002). Creating wetlands for waterfowl in Wyoming. Ecological Engineering, 18, 293-304.

Murray, C. G., \& Hamilton, A. J. (2010). Perspectives on wastewater treatment wetlands and waterbird conservation. Journal of Applied Ecology, 47, 976-985

Omernik, J. M. (1987). Ecoregions of the conterminous United States, map (scale 1:7,500,0000). Annals of the Association of American Geographers, 77, 118-125.

Paracuellos, M., \& Telleria, J. L. (2004). Factors affecting the distribution of a waterbird community: the role of habitat configuration and bird abundance. Waterbirds, 27, 446-453.

Pidgeon, A. M., Radeloff, V. C., Flather, C. H., Lepczyk, C. A., Clanton, M. K., Hawbaker, T. J., \& Hammer, R. B. (2007). Associations of forest bird species richness with housing and landscape patterns across the USA. Ecological Applications, 17, 1989-2010.

Preston, C. R. (1990). Distribution of raptor foraging in relation to prey biomass and habitat structure. Condor, 92, 107-112.

Ricklefs, R. E. (1990). Ecology (3rd ed.). New York, NY: W.H. Freeman.

Sibley, D. A. (2001). The sibley guide to bird life and behavior. New York, NY: Alfred A. Knopf, Inc.

Smith, L. M., Haukos, D. A., \& Prather, R. M. (2004). Avian response to playa wetlands during winter. Wildlife Society Bulletin, 32, 474-480.

Sparling, D. W., Eisemann, J. D., \& Kuenzel, W. (2004). Contaminant exposure and effects in red-winged blackbirds inhabiting stormwater retention ponds. Environmental Management, 33, 719-729.

Sparling, D. W., Eisemann, J. D., \& Kuenzel, W. (2007). Nesting and foraging behavior of red-winged blackbirds in stormwater wetlands. Urban Ecosystems, 10, 1-15.

Steen, D. A., Gibbs, J. P., \& Timmermans, S. T. (2006). Assessing the sensitivity of wetland bird communities to hydrologic change in the eastern Great Lakes region. Wetlands, 26, 605-611.

Stout, W. E., Temple, S. A., \& Cary, J. R. (2006). Landscape features of red-tailed hawk nesting habitat in an urban/suburban environment. Journal of Raptor Research, 40, 181-192.

Traut, A. H., \& Hostetler, M. E. (2003). Urban lakes and waterbirds: effects of development on avian behavior. Waterbirds, 26, 290-302.

U.S. Federal Aviation Administration (FAA). (2007). Advisory circular 150/5200-33B hazardous wildlife attractants on or near airports http://wildlife-mitigation.tc.faa.gov/wildlife/

Weller, M. W., \& Spatcher, C. S. (1965). Role of habitat in the distribution and abundance of marsh birds Special report 43. Ames, IA: Agricultural and Home Economics Experiment Station, Iowa State College.

White, C. L., \& Main, M. B. (2005). Waterbird use of created wetlands in golf-course landscapes. Wildlife Society Bulletin, 33, 411-421. 